\title{
JIEM's third year - Present status and future avenues
}

Mihaela Enache, Vicenc Fernandez, Maria Albareda-Sambola, Pep Simo, Jose M. Sallan

Universitat Politècnica de Catalunya (SPAIN)

mibaela.enache@upc.edu; vicenc.fernander@upc.edu; maria.albareda@upc.edu; pep.simo@upc.edu;

jose.maria.sallan@upc.edu

Abstract: This editorial builds upon the guidelines developed by the Journal of Industrial Engineering and Management (JIEM) since its inception (Sallan et al., 2010; Simo et al., 2009; Fernandez et al., 2008) and reflects some relevant information about the evolution of JIEM during 2010, together with novel features that have been implemented so far or which are planned to be realized.

Keywords: JIEM, editorial, E-PUB, html version

\section{Introduction}

This editorial draws upon the previous one (Sallan et al., 2010) to highlight some relevant data regarding the activity undertaken so far and to reveal the changes planned for the following issues.

The statistics of the journal show a significant increase in the number of manuscripts received $(\mathrm{N}=116)$ during 2010 , as compared with the previous year ( $N=87$ ). During last year, a $33 \%$ of the manuscripts received were accepted, the average reviewing time being 114 days. The number of registered users has doubled with respect to 2009, and reached during the previous year a total of 856 users. The Journal of Industrial Engineering and Management published 30 papers in 2010, encompassed within 3 issues (two general issues and a special one focused on new trends in Management of Technology as a Step to Sustainable Production). 
Table 1 illustrates the number of papers published in each field, disclosed by issue. As reflected in this table, Production is still being the most prolific field, as in 2009; nevertheless we encourage authors from different areas of industrial engineering and industrial management in organizations to submit their original and unpublished manuscripts for evaluation.

\begin{tabular}{|l|c|c|c|}
\hline \multicolumn{1}{|c|}{ Field } & Vol. 3, No. 1 & $\begin{array}{c}\text { Vol. 3, No. 2 } \\
\text { (Special I ssue) }\end{array}$ & Vol. 3, No. 3 \\
\hline Editorial & 1 & 1 & 5 \\
\hline PROD & 5 & 10 & \\
\hline IS & & & 1 \\
\hline IND & 3 & & 1 \\
\hline MANAG & 1 & & 1 \\
\hline FIN & 1 & $\mathbf{1 1}$ & $\mathbf{8}$ \\
\hline EDUC & $\mathbf{1 1}$ & & \\
\hline Total & & & \\
\hline
\end{tabular}

Table 1: Papers published in each field and issue (Volume 3) of JIEM. Source: Editors.

The international character of JIEM is reflected by the diversity of countries in which the publishing authors work (see Figure 1). During 2010, JIEM published papers authored by researchers from 17 countries, the largest number of authors being from USA (13.04\%), followed by Slovenia (11.59\%), Malaysia (11.59\%), India (10.14\%), Croatia (10.14\%), Poland (8.70\%) and Spain (8.70\%).

\section{Country of I nstitution (authors)}

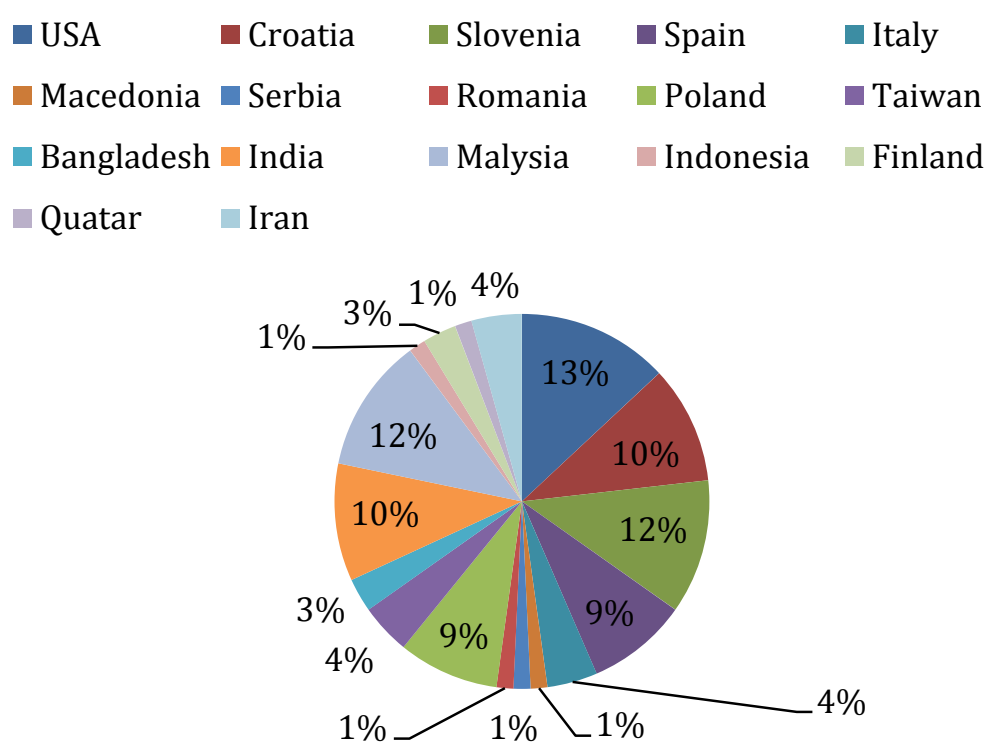

Figure 1. Country of Institution. Source: Editors. 
The heterogeneity of authors in terms of working country allows the journal to publish theoretical and empirical contributions that promote an international perspective on the issues that confront industrial engineering and industrial management.

With respect to the editorial board, we are pleased to announce new members who have joined the board in 2010:

- Helena Ramalhinho Lourenço and Inma Ribas (Production, Logistics and Operational Reserach)

- Veronique Zardet (Management, Organizational Behavior and Human Resources)

- Beatriz Amante (Education, Training and Professional Skills)

The complete list of board members is reported in the journal website (Editorial Team). We would like to thank the editorial board members and the 100 anonymous reviewers for their contribution in reviewing manuscripts submitted to JIEM during 2010.

As mentioned in the previous years, we firmly believe that the prestige and visibility of a journal are highly fostered by its indexation in bibliographical databases. During 2010 we continued working on indexing JIEM in databases useful for its readers and authors and to date, JIEM has been also indexed and abstracted in Carhus + (Agency for Administration of University and Research Grants - CATALONIA/SPAIN), Miar (Information Matrix for Evaluating Journals) and Scopus, the largest abstract and citation database of research literature and quality web sources covering nearly 18,000 titles from more than 5,000 publishers. One of the next challenges is the inclusion of the journal in the ISI WEB, specifically in the Sciences Citation Index, which would continue significantly raising the visibility of the papers published in the journal. We keep being committed to work in this direction, along with our reviewers, Editorial Board members and authors. The complete list of databases in which JIEM has been listed can be found at http://jiem.org/index.php/jiem/about/editorialPolicies\#custom- 0 .

As a novelty with regard to 2009, the papers published in JIEM are now also available in EPUB format, a modern, industry standard format developed by the International Digital Publishing Forum as an XML format for reflowable digital books 
and publications. Moreover, the printed edition of the Journal of Industrial Engineering and Management (JIEM) has been launched, and paper copies have been issued of all old numbers. To acquire any of them, please follow the following link http://jiem.org/index.php/jiem/about/editorialPolicies\#custom1. Although there is a small charge for ordering the printed version, we would like to stress that JIEM is an open access journal and for the online edition, the journal makes no page charges to authors.

Finally, we are pleased to announce readers that we are preparing a special issue that will include the best papers presented at the International Conference on Value Chain Sustainability, that was held at Universidad Politècnica de Valencia (Valencia, Spain), November 15-17 and was devoted at discussing and examining how the unique triangle of product/service design, logistics, and branding can be integrated and balanced in order to develop sustainable value chains unlocking new sources of Competitiveness in Manufacturing and Service Supply Chains. In future we also plan to publish papers in html version and we invite and encourage authors to send us their conceptual and/or empirical original papers that contribute in advancing knowledge and understanding of phenomena related with all aspects of industrial engineering and industrial management.

\section{References}

Sallan, J. M., Enache, M., Albareda, M., Fernandez, V., \& Simo, P. (2010). An overview of JIEM's second year, and a prospect of its third. Journal of Industrial Engineering and Management, 3(1), 1-10.

doi:10.3926/jiem.2010.v3n1.p1-10

Simo, P., Enache, M., Sallan, J. M., \& Fernandez, V. (2009). First year reflections: Basic Guidelines and future directions. Journal of Industrial Engineering and Management, 2(1), 1-9.

doi: 10.3926/jiem.2009.v2n1.p1-9

Fernandez, V., Simo, P., Sallan, J. M., \& Enache, M. (2008). JIEM: A new exciting journey into the research of industrial engineering and management. Journal of Industrial Engineering and Management, 1(1), 1-3.

doi: 10.3926/jiem.2008.v1n1.p1-3 
Article's contents are provided on a Attribution-Non Commercial 3.0 Creative commons license. Readers are allowed to copy, distribute and communicate article's contents, provided the author's and Journal of Industrial Engineering and Management's names are included. It must not be used for commercial purposes. To see the complete license contents, please visit http://creativecommons.org/licenses/by-nc/3.0/. 